\title{
RELEVANCE OF VO max CONSUMPTION IN ELITE BULGARIAN TAEKWONDO COMPETITORS
}

\author{
Dimitar Avramov
}

National Sports Academy "Vassil Levski", Sofia, Bulgaria

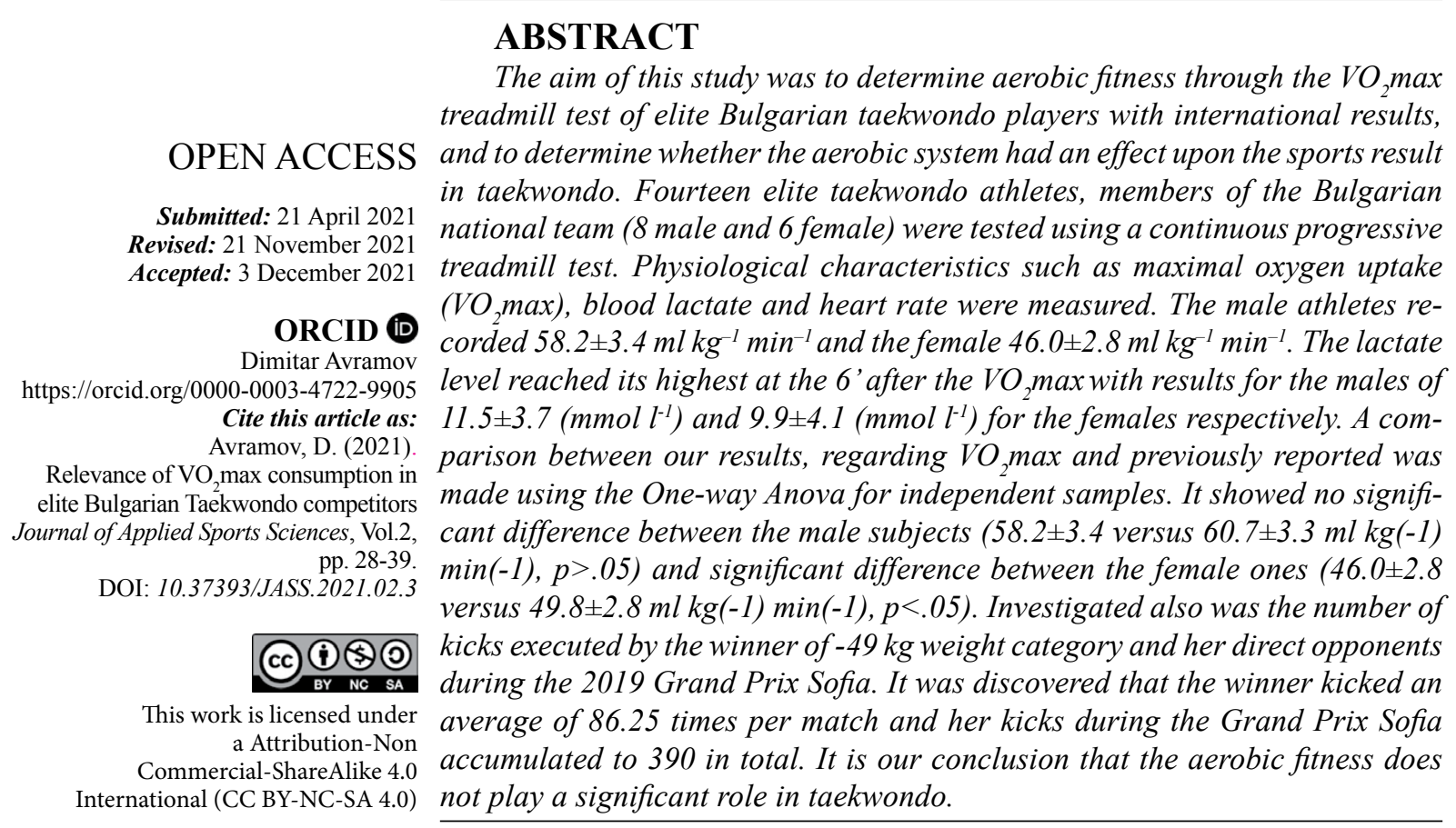

Keywords: Taekwondo, $\mathrm{VO}_{2} \max$, Anaerobic, Endurance, Aerobic

\section{INTRODUCTION}

Determining the primary energy source in every sport is vital for the optimization of the training process. In endurance sports it is of key importance to identify the type of endurance needed whether it will be aerobic, anaerobic or of mixed type. The most widely used aerobic capacity indicator is the maximal oxygen uptake $\left(\mathrm{VO}_{2} \max \right)$, which is defined as the highest rate of oxygen consumption attainable during maximal or exhaustive exercise" (Dimitrova et al., 2019). The measurement of $\mathrm{VO}_{2}$ max in a laboratory provides quantitative value of endurance for comparison of the individual training effect, as well as comparison of endurance between different athletes. In addition to the $\mathrm{VO}_{2}$ max testing, the measurement of blood lactate in sporting activities provides useful in- formation to athletes, coaches and sports scientists for individualizing training programs and also for evaluating the effectiveness of the training programs (Kitagawa, 2010).

Taekwondo has been an Olympic sport for the past 21 years. Even though there are several competitive disciplines such as sparring (kyorugi), forms (poomsae) and breaking (kyokpa) only the first discipline is an official Olympic event. The sparring is also the most demanding of the three regarding the physiological functions of an athlete. Taekwondo matches usually consist of 3 rounds of 2 minutes, divided by 1 minute break between each. In order to win a gold medal, an athlete must win 5 or 6 matches during the World Championships (Results, World Taekwondo Championships, 2019). The matches are usually conducted in 
one day which puts an enormous stress upon the body of the competitor. During the last two World championships (2017 Muju, 2019 Manchester) the final games for each category were scheduled for the next day in order for the athletes to have more time to recover and perform better. However, other championships, including the Olympics are held on one day.

Even though it is still debatable whether the aerobic energy system is of great consequence in taekwondo, few studies have been conducted on the topic of aerobic fitness in elite taekwondo athletes (Markovic, 2005, Rivera, 1998). Furthermore, most of the studies on the subject have been performed prior the changes in the rules regarding the electronic scoring system which has affected the dynamics and intensity of the taekwondo match drastically. That is why, we deemed necessary to examine the effect of these changes upon the athletes utilizing the most standardized and used test for aerobic endurance.

The aim of this study was to examine the maximal oxygen consumption in taekwondo players and its role in the sports result and to determine whether the new style of play, imposed by the changes in the competition rules of taekwondo, had an effect over the aerobic fitness of the athletes.

For that purpose, we compared our results regarding $\mathrm{VO}_{2}$ max test of taekwondo athletes with previously reported ones, acquired under the old competition rules. We also investigated the number of kicks performed during a taekwondo competition under both set of rules.

The taekwondo kicks rely on anaerobic power but there have been little attempts to standardize specific anaerobic endurance tests for taekwondo (Jader et al., 2014). Another problem is that there have been little to no consequential data of application of those tests. In a summary of all the physical and physiological data of taekwondo athletes available made by Craig et al. (2014) the Wingate test is the only non-specific test for anaerobic power done in taekwondo. Another problem presents the wide range of weight categories in taekwondo and the limited data reported for each category respectively.

Given the broad range of sports that use the maximum oxygen uptake test, it is relatively easy to compare the results from $\mathrm{VO}_{2}$ max between different sports. It is still debatable how instrumental for the taekwondo athlete the aerobic fitness is, but it is mandatory for Bulgarian national teams to undergo functional tests every year and the $\mathrm{VO}_{2}$ max test is the only functional test that is done for taekwondo athletes in Bulgaria.

\section{MATERIALS AND METHODS Participants}

Fourteen Bulgarian national team athletes ( 8 male and 6 female) voluntarily took part in the study as a part of their annual testing. Each athlete signed an informed consent form before participation in the study. Ethical clearance was obtained from the Bulgarian Taekwondo Federation. The inclusion criteria for the participants were to be active members of the Bulgarian national taekwondo team, to have won medals from $\mathrm{G}$ ranking tournaments for seniors and/or juniors and to be in a condition to perform the test.

All participants had a minimum of $8+$ years of experience (black belts) that trained $10 \pm$ 2 sessions per week with mean age of 17.6 years; body height $174.3 \pm 7.7 \mathrm{~cm}$ for the males and $165.7 \pm 5.6 \mathrm{~cm}$ for the females; body mass $62.0 \pm 8.3 \mathrm{~kg}$ for the males and $55.7 \pm 6.7 \mathrm{~kg}$ for the females.

The subjects were in a basic preparation period and according to the annual periodization plan were training an average of 22 hours per week, with a weekly average of 8 hours spent on basic physical preparation, 8 hours spent 
on specific physical preparation, 4 hours spent on technical preparation and 2 hours spent on psychological preparation.

All subjects and their parents (for those under 18-years-old) were informed in advance about the procedures of the study and asked to sign a term of consent according to the Declaration of Helsinki.

\section{Testing procedures}

The test was performed on the 12 and 13 of December 2019. The athletes were invited for two consecutive internship weekends for testing. This period coincided with the post competitive phase of the season and the basic preparation period. The testing was conducted between 10 a.m. and 2 p.m. each testing day.

\section{Anthropometric measurements}

Anthropometric measurements such as body mass, body height and 10 skinfolds (1. Skinfold on the cheek underneath the temple at the level of the tragus. 2. Under the chin above the hyoid hone. 3. On the chest in the anterior axillary fold. 4 . On the back of the arm halfway between the acromion and olecranon. 5. On the back underneath the angle of the scapula. 6. On the abdomen in the first quarter of the distance between the anterior spike of the ilium and the umbilicus. 7. On the chest in the anterior axillary line at the level of the tenth rib. 8. On the side above the iliac crest in the prolongation of the anterior axillary line. 9. On the thigh above the knee. 10. On the calf below the popliteal fossa) were measured using a Harpenden caliper model HSK-BI (Great Britain). The percentage of body fat was estimated according to the method of (Parizkova, Buzkova, 1971).

$\% \mathrm{BF}$ male $=22,32 \cdot \log \Sigma \mathrm{X}-29,25$

$\% \mathrm{BF}$ female $=39,57 \cdot \log \Sigma \mathrm{X}-61,25$

where $\Sigma X$ is the sum of the 10 skinfolds

Lean body mass was calculated by subtracting the estimated body fat from the total body mass.

Lean Body Mass $(\mathrm{kg})=\mathrm{BW}-\mathrm{BF}$

$$
\text { Muscle mass } \%=\frac{\text { Body height x }\left(0,0553 . \mathrm{CTC}^{2}+0,0987 . \mathrm{O \Pi}^{2}+0,0331 . \mathrm{CSC}^{2}\right)-2445}{1000}
$$

CTC - Corrected Thigh Circumference CSC - Corrected Shin Circumference
FC - Uncorrected Forearm Circumference SF - Skinfold

$$
\begin{aligned}
\mathrm{CTC}(\mathrm{cm})=\text { Thigh circumference }-\frac{2 . \pi . \mathrm{SF} \text { thigh }}{10} \\
\mathrm{CSC}(\mathrm{cm})=\text { shin circumference } \frac{2 . \pi . \mathrm{SF} \text { shin }}{10}
\end{aligned}
$$

$\mathrm{BF} /$ weight $_{\mathrm{kg}} \times 100=\mathrm{BF}_{\%}$

The testing session included anthropometric measurements, followed by maximal oxygen uptake $\left(\mathrm{VO}_{2} \max\right.$ test). For the treadmill test COSMOS h/p Venus (Germany) treadmill was used. The initial speed of the treadmill was $5 \mathrm{~km} / \mathrm{h}$ and the speed was increased with 1.2 $\mathrm{km} / \mathrm{h}$ at every 90 seconds until failure (exhaus-
$\mathrm{BF}_{\mathrm{kg}}=\mathrm{BF}_{\%} \mathrm{x}$ weight $\mathrm{kg}_{\mathrm{kg}} / 100$

tion). The incline was at constant $2.5^{\circ}$. Gas exchange was monitored during and $10 \mathrm{~min}$ after the exercise. The attainment of $\mathrm{VO}_{2}$ max was validated if at least two of the following criteria were met: (1) reaching a plateau in $\mathrm{VO}_{2}$ max with an increase of the power output; (2) a respiratory exchange ratio $\geq 1.1$; (3) the heart rate 
approaches $( \pm 10 \%)$ the age-predicted maximal heart rate (220-ages) and (4) or volitional fatigue. Maximal oxygen uptake was defined as the maximal attained $\mathrm{VO}_{2}$ at the end of the exercise period in which the subject reached exhaustion. Breath by breath gas exchange was measured continuously with Oxicon Pro (Yeger, Germany). Heart rate was recorded with POLAR RCX3. The recording started at rest and continued until $10 \mathrm{~min}$ post exercise (recovery period). Blood samples were taken from the fingertip to measure blood lactate with the use of an Accutrend Plus (Roche, Switzerland) at 2', 6' and 15'.

We also analyzed the number of kicks executed by the winner and her direct opponents in the female under $49 \mathrm{~kg}$ category at the 2019 Grand Prix Sofia.

\section{Statistical analysis}

All data were analyzed using SPSS, ver- sion 23.0 for Windows (IBM corp. Inc., Chicago, IL, USA, 2015.

Standard statistical methods were used for the calculation of means and standard deviations (SD) and Student's t criterion for independent samples. The differences between the male and female group were reported as mean difference $\pm 95 \%$ confidence intervals (meandiff $\pm 95 \%$ CI). One-way Anova for independent samples was used to determine the differences in $\mathrm{VO}_{2}$ max parameters between our results and previously reported ones. The $p<.05$ was considered as statistically significant.

\section{RESULTS}

The anthropometrical and body composition characteristics of the Bulgarian National team are presented in Table 1 as Mean Value and Standard Deviation. The results from the $\mathrm{VO}_{2}$ max and lactate testing can also be seen there.

Table 1. Anthropometric and functional characteristics of the Bulgarian national taekwondo team $($ Mean $\pm S D)$

\begin{tabular}{lcc}
\hline Variable & Male & Female \\
\hline Number of participants & 8 & 6 \\
Height $(\mathrm{cm})$ & $174.3 \pm 7.7$ & $165.7 \pm 5.6$ \\
Range & $176.3 \pm 8.6$ & $162.5 \pm 5.3$ \\
Body mass (kg) & $62.0 \pm 8.3$ & $55.7 \pm 6.7$ \\
Lean Body Mass (kg) & $56.8 \pm 7.5$ & $46.3 \pm 3.9$ \\
\% Body fat & $8.0 \pm 2.5$ & $16.4 \pm 3.3$ \\
Body fat (kg) & $5.2 \pm 1.5$ & $9.3 \pm 2.9$ \\
\% Muscle mass & $47.9 \pm 2.1$ & $41.9 \pm 2.1$ \\
Muscle mass (kg) & $29.8 \pm 4.8$ & $23.2 \pm 2.2$ \\
S max & $15.1 \pm 1.1$ & $11.7 \pm 0.6$ \\
VO max $_{\text {VO }}$ max/kg & $3603.1 \pm 433$ & $2568.1 \pm 353.0$ \\
HR max & $58.2 \pm 3.4$ & $46.0 \pm 2.8$ \\
La 2' & $195.1 \pm 7.6$ & $191.5 \pm 6.4$ \\
La 6' & $9.0 \pm 3.0$ & $7.9 \pm 3.4$ \\
La 15' & $11.5 \pm 3.7$ & $9.9 \pm 4.1$ \\
HR 2' & $7.8 \pm 5.3$ & $7.0 \pm 3.3$ \\
HR 6' & $145.8 \pm 17.6$ & $146.7 \pm 9.5$ \\
\hline
\end{tabular}


Table 2 presents the age and body composition obtained by us compared to a previously published data. It must be noted that Heller (Heller et al., 1998) tested taekwondo athletes from the International Taekwondo Federation, which differs from the Olympic style Taekwondo in terms of competition rules - hence - the difference in the obtained results.

Table 2. Age and body composition of female taekwondo athletes (MEAN $\pm S D$ )

\begin{tabular}{lcccc}
\hline \multicolumn{1}{c}{ Variable } & $\begin{array}{c}\text { Bulgarian } \\
\text { National } \\
\text { Team }\end{array}$ & $\begin{array}{c}\text { Croatian National } \\
\text { team (Markovic } \\
\text { et al., 2005) }\end{array}$ & $\begin{array}{c}\text { Czech National } \\
\text { team (Heller et al., } \\
\text { 1998) }\end{array}$ & $\begin{array}{c}\text { Olympic Puerto } \\
\text { Rican athletes } \\
\text { (Rivera et al., 1998) }\end{array}$ \\
\hline No. of athletes & 6 & 13 & 12 & 9 \\
Age (years) & $17.6 \pm 0.5$ & $21.5 \pm 4.1$ & $18.5 \pm 2.6$ & $18.1 \pm 3.4$ \\
Body mass (kg) & $55.7 \pm 6.71$ & $60.1 \pm 9.0$ & $62.3 \pm 7.4$ & $58.6 \pm 11.2$ \\
Body height $(\mathrm{cm})$ & $165.7 \pm 5.6$ & $168.0 \pm 6.6$ & $168.0 \pm 5.0$ & $163.7 \pm 6.9$ \\
Body fat $(\%)$ & $16.4 \pm 3.3$ & $16.5 \pm 2.7$ & $15.4 \pm 5.1$ & $18.3 \pm 5.6$ \\
Lean body mass $(\mathrm{kg})$ & $46.3 \pm 3.9$ & $49.9 \pm 5.8$ & $52.4 \pm 4.2$ & - \\
\hline
\end{tabular}

The use of weight categories in taekwondo supposes that the athletes should have lower percentage of body fat. It is important in which period of the yearly cycle the athletes have been tested since the weight in the preparatory and in the competition period differs significantly. The Bulgarian athletes were tested in December when the competitive period was over and they were into a basic preparation. The tested Bulgarian female ath- letes are in the lower weight categories (49, 53 and $57 \mathrm{~kg}$ ).

The female physical characteristics are comparable to the ones Markovic et al. (2005) have reported. However, Markovic divided his test subjects to two groups - A and B. In A were the athletes with significant international results. When compared to them the Bulgarian athletes are with lower indicators.

Table 3. Age and body composition of male taekwondo athletes (MEAN $\pm S D$ )

\begin{tabular}{lcccc}
\hline \multicolumn{1}{c}{ Variable } & $\begin{array}{c}\text { Bulgarian } \\
\text { National } \\
\text { Team }\end{array}$ & $\begin{array}{c}\text { Turkish elite } \\
\text { (Khayyat et al., } \\
\mathbf{2 0 2 0}\end{array}$ & $\begin{array}{c}\text { Czech National } \\
\text { team (Heller et al., }\end{array}$ & $\begin{array}{c}\text { Olympic Puerto } \\
\text { Rican athletes } \\
\text { (Rivera et al., 1998) }\end{array}$ \\
\hline No. of athletes & 8 & 12 & 11 & 13 \\
Age (years) & $17.0 \pm 1.3$ & $22.7 \pm 2.8$ & $20.9 \pm 2.2$ & $22.3 \pm 7.1$ \\
Body mass (kg) & $62.0 \pm 8.39$ & $72.9 \pm 6.9$ & $69.9 \pm 8.7$ & $67.1 \pm 11.8$ \\
Body height (cm) & $174.3 \pm 7.7$ & $182.0 \pm 0.4$ & $179 \pm 6$ & $171.2 \pm 5.8$ \\
Body fat (\%) & $8.0 \pm 2.5$ & $12.8 \pm 3.4$ & $8.2 \pm 3.1$ & $9.6 \pm 2.7$ \\
Lean body mass $(\mathrm{kg})$ & $56.8 \pm 7.5$ & $\mathrm{~N} / \mathrm{A}$ & $64.2 \pm 6.7$ & N/A \\
\hline
\end{tabular}

For body composition comparison we body fat percentage compared to the other testdeem proper certain category to be compared ed subjects described. The tested competitors and examined in terms of height and body fat. are however of the lower weight categories However, such a research has not been per- $(54,58,63,68$ and $74 \mathrm{~kg})$ which can also be formed. Bulgarian athletes have the lowest seen in Table 3. 
Table 4. Functional characteristics of elite female taekwondo athletes (Mean $\pm S D$ )

\begin{tabular}{lcccc}
\hline Variable & $\begin{array}{c}\text { Bulgarian Na- } \\
\text { tional Team }\end{array}$ & $\begin{array}{c}\text { Croatian National } \\
\text { team - All (Mar- } \\
\text { kovic et al., 2005) }\end{array}$ & $\begin{array}{c}\text { Croatian National } \\
\text { team Elite (Mar- } \\
\text { kovic et al., 2005) }\end{array}$ & $\begin{array}{c}\text { Czech ath- } \\
\text { letes (Heller } \\
\text { et al., 1998) }\end{array}$ \\
\hline $\mathrm{VO}_{2}$ max (1 min-1) & $2.5 \pm 0.3$ & $2.9 \pm 0.5$ & $3.1 \pm 0.5$ & N/A \\
$\mathrm{VO}_{2}$ max (ml.kg-1.min-1) & $46.0 \pm 2.8$ & $48.3 \pm 2.8$ & $49.6 \pm 3.3$ & $41.6 \pm 4.2$ \\
Maximum Heart rate & $191.1 \pm 6.4$ & N/A & N/A & $188 \pm 8$ \\
\hline
\end{tabular}

Table 4 presents the obtained data for investigation performed by Markovic et al., $\mathrm{VO}_{2} \max$ of female taekwondo athletes. In 2005 resembles ours the most. That is why, terms of the number and level of participants, we compared our results to his findings. and the method of testing (Treadmill test), the

Table 5. Mean values of the surveyed indexes for the Bulgarian and Croatian female national teams (Mean $\pm S D)$

\begin{tabular}{lcccc}
\hline \multicolumn{1}{c}{ Variable } & $\mathbf{N}$ & VO $_{2}$ max (ml.kg-1.min-1) & temp & P(t) \\
\hline Bulgarian National team & 8 & $46.0 \pm 2.8$ & \multirow{2}{*}{2.44} & \multirow{2}{*}{98.00} \\
Croatian National team & 7 & $49.8 \pm 2.8$ & & \\
\hline
\end{tabular}

A significant difference was discovered between the Bulgarian and the Croatian female athletes (Table 5). The Bulgarian female athletes had lesser $\mathrm{VO}_{2}$ max uptake than their Croatian counterparts but they are much young- er, which we consider to be one of the main reasons for that difference (Bulgarian female athletes $17.6 \pm 0.5$ years versus Croatian female athletes $21.5 \pm 4.1$ years).

Table 6. Functional characteristics of elite male taekwondo athletes (Mean $\pm S D$ )

\begin{tabular}{lcccc}
\hline \multicolumn{1}{c}{ Variable } & $\begin{array}{c}\text { Bulgarian } \\
\text { National } \\
\text { team }\end{array}$ & $\begin{array}{c}\text { Division I } \\
(\text { Chen et al., } \\
\text { 2006) }\end{array}$ & $\begin{array}{c}\text { Czech National } \\
\text { ITF team (Heller et al., } \\
\text { 1998) }\end{array}$ & $\begin{array}{c}\text { Olympic Puerto Rican } \\
\text { athletes (Rivera et al., } \\
\text { 1998) }\end{array}$ \\
\hline $\begin{array}{l}\mathrm{VO}_{2} \text { max } \\
(1 \mathrm{~min}-1)\end{array}$ & $3.6 \pm 0.4$ & $\mathrm{~N} / \mathrm{A}$ & $\mathrm{N} / \mathrm{A}$ & $\mathrm{N} / \mathrm{A}$ \\
$\begin{array}{l}\mathrm{VO}_{2} \text { max } \\
(\mathrm{ml} . \mathrm{kg}-1 . \mathrm{min}-1)\end{array}$ & $58.2 \pm 3.4$ & $53.1 \pm 2.0$ & $53.9 \pm 4.4$ & $59.3 \pm 4.5$ \\
$\begin{array}{l}\text { Maximum speed } \\
\text { (km h-1) }\end{array}$ & $15.1 \pm 1.1$ & $\mathrm{~N} / \mathrm{A}$ & $\mathrm{N} / \mathrm{A}$ & $14.9 \pm 0.7$ \\
$\begin{array}{l}\text { Max Heart rate } \\
\text { (beats min-1) }\end{array}$ & $195.1 \pm 7.6$ & $195.3 \pm 2.8$ & $183 \pm 6$ & $171.0 \pm 8.2$ \\
\hline
\end{tabular}

Regarding the male oxygen uptake, a comparison was made with the oxygen uptake reported by Drabik (1995) which was closest to ours in terms of the number and level of participants, and the method of testing (Treadmill test). 
Table 7. Mean values of the surveyed indexes of the Bulgarian and Polish male national teams (Means $\pm S D$ )

\begin{tabular}{llccc}
\hline \multicolumn{1}{c}{ Variable } & N & VO $\mathbf{m a x}(\mathbf{m l . k g}-1 . \mathbf{m i n}-\mathbf{1})$ & temp & P(t) \\
\hline Bulgarian National team & 6 & $58.2 \pm 3.4$ & \multirow{2}{*}{1.44} & \multirow{2}{*}{82.00} \\
Polish National team (Drabik 1995) & 7 & $60.7 \pm 3.3$ & & \\
\hline
\end{tabular}

We found no statistical difference in the compared results (Table 7). There are few published studies involving elite national team athletes from top countries in taekwondo regarding $\mathrm{VO}_{2}$ max. There are even fewer studies published since the major changes in the competition rules. We deemed necessary to inter- pret the aerobic endurance in relationship to the taekwondo activity during a match.

In terms of special endurance, we deemed correct to interpret any results from standardized tests to specific workload. That is why, we chose to investigate the number of kicks executed in a taekwondo match.

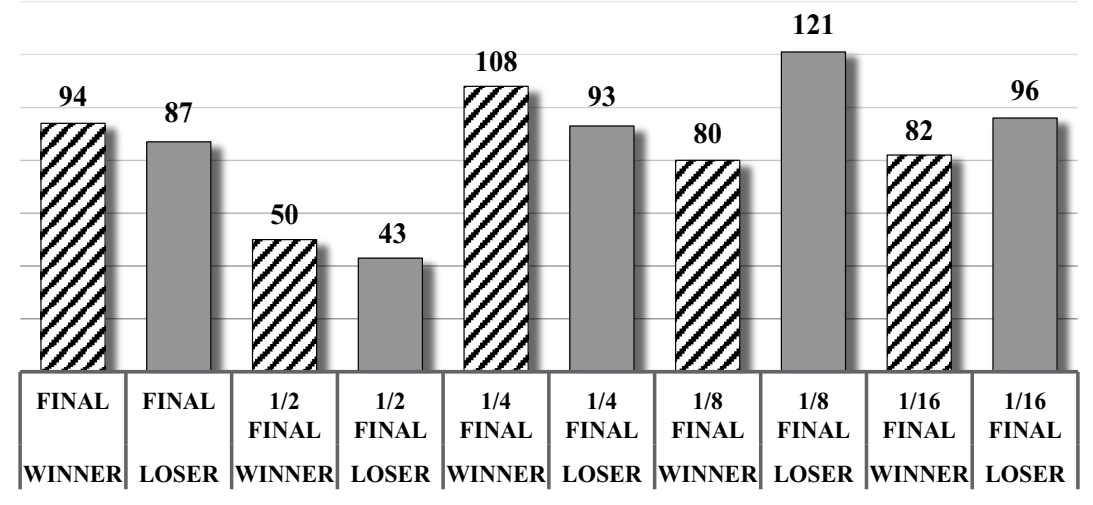

Figure 1. Total number of kicks and punches in a taekwondo match

We managed to count the total number of to previously reported values by Markovic et kicks and punches for the $49 \mathrm{~kg}$ female weight al. (2008) and Falco et al. (2012), ours were 3 category winner at the 2019 Grand Prix Sofia. times higher.

The results are presented in Figure 1. Compared

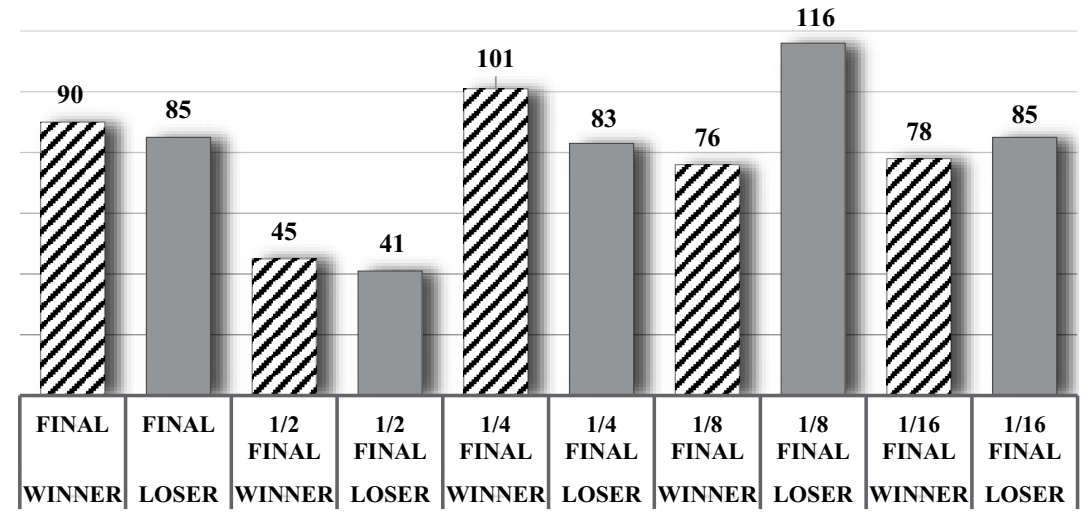

Figure 2. Total number of kicks performed in a taekwondo match 
Since the main tool for scoring points in is not relevant to the present study and that is Olympic taekwondo is kicking it is important to know how many times per match a competitor is doing it. Figure 2 presents the number of kicks the winner of the $-49 \mathrm{~kg}$ female weight category executed in all her games during Grand Prix Sofia 2019. The types of kicks used why we have not included them in here. Bear in mind that during the semi-final of Grand Prix Sofia between the winner and the loser, the latter had an injury and the total three rounds of the match were not played. We have not included that match in the average numbers.

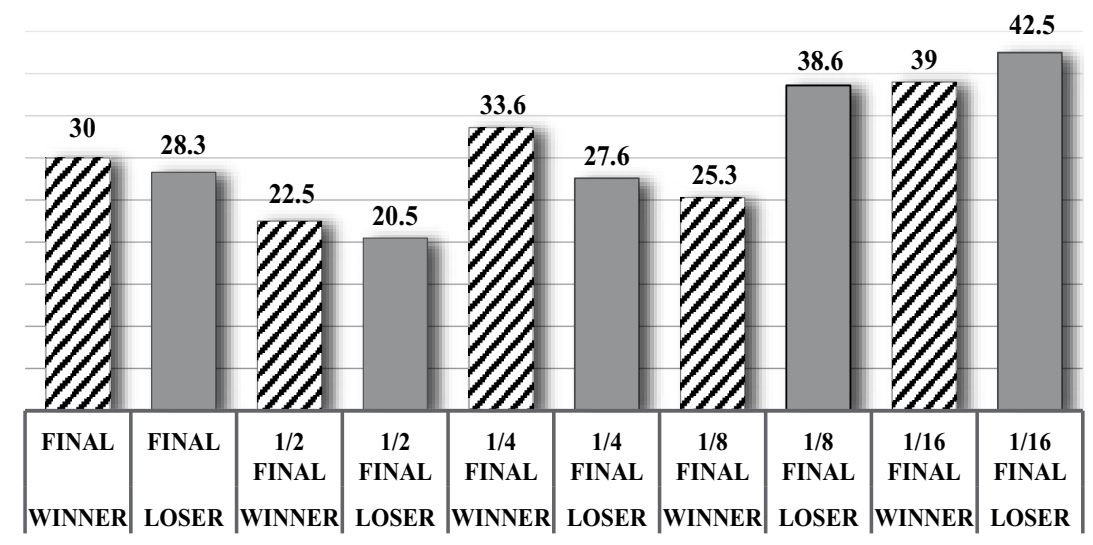

Figure 3. Average number of kicks per taekwondo round

Figure 3 clearly shows that the number of executed kicks in a modern taekwondo fight has grown significantly than previously reported values. The number of kicks in a single round in modern taekwondo equals those reported by Markovic et al. (2008) and Falco et al. (2012) for an entire match.

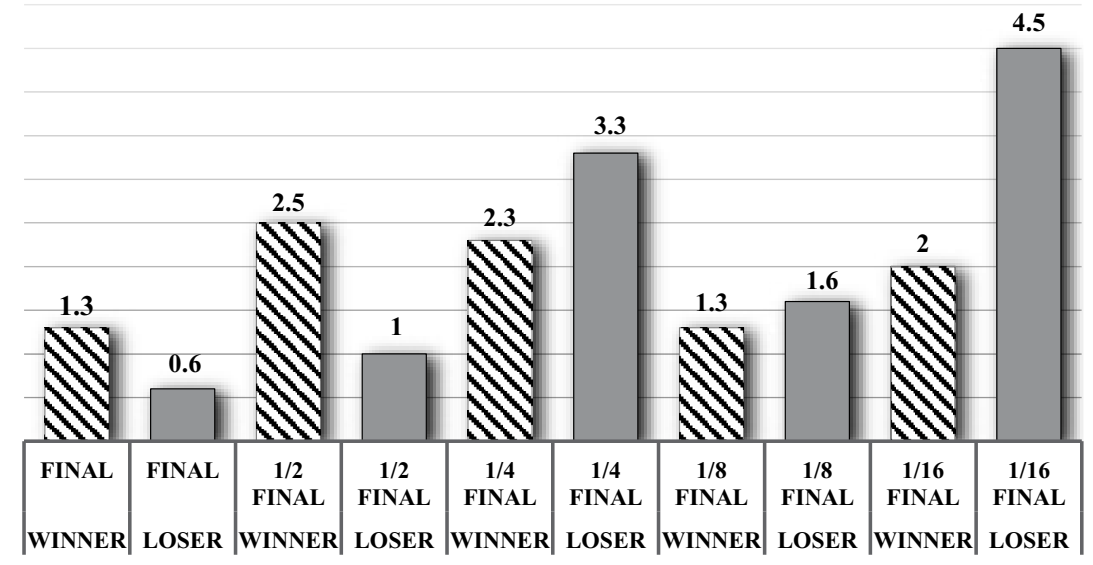

Figure 4. Average number of punches per taekwondo round

Punching is still the only hitting technique in taekwondo that is scored by the referees and it is very subjective whether a referee would award it or not. The numbers shown in Figure 4 suggest that punching is still not widely used in modern taekwondo but further inves- tigation is needed as to establish the influence punching techniques play over the sport result in taekwondo.

\section{DISCUSSION}

Markovic et al. (2005) consider that ade- 
quate aerobic capacity is indispensable because it enables relatively fast recovery between rounds and fights and also facilitates faster recovery during and after a training session. However, Elliot et al. (2007) state that "...the development of LIEE (Low Intensity Exercise Endurance) in sports that rely on anaerobic endurance supply (e.g., sprinting, American football, ice hockey, volleyball) can result in maladaptation that reduces an athlete's performance capacity”. Bompa, Buzzichelli (2015) suggests the following information regarding the bioenergetic characteristics for some sports.

Table 8. Energy Delivery Systems (Ergogenesis in Percentage) for Sports

\begin{tabular}{lccccc}
\hline Sport & $\begin{array}{c}\text { Event or } \\
\text { position }\end{array}$ & $\begin{array}{c}\text { ATP + Creatine } \\
\text { phosphate }\end{array}$ & Glycolytic & Oxidative & Reference \\
\hline $\begin{array}{l}\text { Athletics (track } \\
\text { and field) }\end{array}$ & $200 \mathrm{~m}$ & 26 & 45 & 29 & $\begin{array}{c}\text { (Someren, 2006) and News- } \\
\text { holme et al. (1994) }\end{array}$ \\
& $400 \mathrm{~m}$ & 12 & 50 & 38 & $\begin{array}{c}\text { Someren, 2006) and News- } \\
\text { holme et al. (1994) }\end{array}$ \\
& 800 & 6 & 33 & 61 & $\begin{array}{c}\text { (Someren, 2006) and News- } \\
\text { holme et al. (1994) } \\
\text { Judo }\end{array}$ \\
\begin{tabular}{l} 
Wrestling \\
\hline
\end{tabular} & 90 & 10 & 0 & $\begin{array}{c}\text { (Dal Monte, 1983) } \\
\text { (Powers and Howley, 2004) }\end{array}$ \\
\hline
\end{tabular}

One of the biggest misconceptions conditioning coaches have about taekwondo is to compare the 2-minute taekwondo round to a track and field event with the relatively same duration, most often $800 \mathrm{~m}$ dash. Very often only the duration of the events is taken into the consideration. However, during the $800 \mathrm{~m}$ the load of the event is constant and of a submaximal intensity while during the taekwondo round there are short bursts of energy (kicks, punches, slides or steps, blocking, pushing), preferably with maximum intensity, which last from less than 1 second $(0.498 \pm 0.021 \mathrm{~s})$ (Estevan 2013) for 1 kick to a combination of 3-4 kicks the most (4-5 seconds). This is followed by a period of a relative rest (bouncing or standing still and/or preparing for the next attack). There are also the breaks in the game which are inevitable - from 5 seconds (when there is a penalty to be given to a competitor), to a 1-3 minute when a coach has requested a video replay.

Elite female taekwondo athletes have been reported to deliver an average of 32.1 kicks in a taekwondo bout (Markovic et al. (2008). Falco et al. (2012) reports between 28.4 and 34.25 of kicks for the different categories for the male and between 26.5 and 45.17 for the female categories in 2011 Spanish University championships. We considered these numbers to be outdated having in mind that there have been significant changes in the competition rules of taekwondo (World Taekwondo, 2019; World Taekwondo Federation, 2009). That consideration was confirmed by our results and given the number of kicks that we have reported an average of almost 90 per match per athlete $(M=89.25)$. This equals to around 1 kick per every 4 seconds in a taekwondo match. In reality those numbers (depending on the type of kicks) accumulate relatively to 45 seconds of High Intensity Movements during a taekwondo match regarding the number of kicks.

It is obvious that Taekwondo relies primarily on power and speed endurance since it incorporates high power outputs and repeti- 
tive performance of high velocity movements (kicks). The ability to sustain and repeat high intensity exercise bouts is termed high-intensity exercise endurance (HIEE) (Stone et al., 2006). Not only is HIEE or interval training approach beneficial to and does not impair the force generating capacity (Bompa, Buzzichelli, 2015), but it can also be beneficial to aerobic endurance or LIEE (Laursen, Jenkins, 2002). This means that taekwondo athletes will develop the needed aerobic capacity even if they perform High Intensity Interval Work with the sport specific exercises.

\section{CONCLUSION}

Speed and Power endurance is inevitably linked to the anaerobic system. However, according to proposed models for a training microcycle in power dependent sports (Bompa, Buzzichelli, 2019), the alternation between lactic, alactic and aerobic system is inevitable. This can be incorporated in taekwondo when the aerobic energy system is taxed during technical and tactical trainings, especially when using a partner if the intensity of the exercises is not high and/or after a heavy load day. The specifics of taekwondo trainings even for elite athletes include numerous repetitions of a skill both technical and/or tactical. Those can be done on the aerobic days serving a double function - first to develop the new skill and second to recover the energy system (either alactic or lactic).

The results from the $\mathrm{VO}_{2}$ max test regarding the Bulgarian and the previously reported Polish national team male athletes (Drabik, 1995) suggest that the aerobic capacity has not changed in the taekwondo athlete. We presume that this is due to the fact that the aerobic capacity does not play a significant role in the preparation of a taekwondo competitor.

In terms of the female athletes, even though there is a statistically significant difference be- tween the two groups, we consider this mainly due to the fact that the Bulgarian athletes are much younger than their Croatian counterparts and not because the aerobic fitness plays an important role in the preparation and the consequent success of a taekwondo female competitor. Furthermore, given the number of kicks reported by us and the values of the $\mathrm{VO}_{2}$ max test it is our conclusion that aerobic endurance is not an important factor of the sports result in taekwondo. It is a secondary quality and is developed during the technical and occasionally tactical training. That is why we consider that there is no need in the additional development of that quality in elite taekwondo athletes.

We recommend that instead of aerobic $\mathrm{VO}_{2}$ max test a specific anaerobic test is developed in order for elite Bulgarian taekwondo athletes to be tested accordingly. Furthermore, we recommend that coaches plan the testing of aerobic and/or anaerobic endurance before and after the planned period for the considered physical quality which has not been the case in the Bulgarian national taekwondo team so far.

\section{LIMITATIONS}

The number of participants in the present study is a limitation. There are also insufficient data in relation to the different weight categories in taekwondo and the corresponding level of physical abilities required for them which presents another limitation in terms of interpretation of the results. In order to obtain best results, the regular testing for the national taekwondo team must be planned according to the training plan and performed before and after the period designated for the development of the specific motor ability. This has not been done so far. There are very few publications regarding elite taekwondo athletes and their motor abilities which is another limitation encountered. 


\section{REFERENCE}

Bompa, T. \& Buzzichelli, C. (2015). Periodization training for sports. 3. Champaign: Human Kinetics.

Bompa, T. \& Buzzichelli C. (2019). Periodization: theory and methodology of training. Champaign: Human Kinetics.

Bridge,C. A., Ferreira da Silva Santos, J., Chaabene, H., Pieter, W. \& Franchini, E. (2014). Physical and psysiological profile of taekwondo athletes. Sports medicine, pp. 713-733. https://doi.org/10.1007/s40279-0140159-9

Chen, J., Lin, Z. \& Esposito, R. (2006). Physiological Profile of Male Tae Kwon Do Athletes In Both Group I and Group II in Division I. The sport digest vol. 14 number 1. http:// thesportdigest.com/archive/article/physiological-profile-male-tae-kwon-do-athletes-bothgroup-i-and-group-ii-division-i.

Dal Monte, A. (1983). The functional values of sport. Firente: Sansoni.

Drabik, P. (1995). Estimation of the anaerobic threshold in male taekwondo athletes by using six different methods. Biol. Sport, 12: 25-34.

Dimitrova, D., Mladenov, L., Nikolova, A. (2019). Aerobic capacity of Judo players scaled for differences in body size. Journal of Applied Sports Sciences, Vol 2, NSA Press, pp 22-36

Elliott, M. C., Wagner, P. P., \& Chiu, L. (2007). Power athletes and distance training: physiological and biomechanical rationale for change. Sports medicine (Auckland, N.Z.), 37(1), 47-57. https://doi. org/10.2165/00007256-200737010-00004

Estevan, I., Falco, C. (2013). Mechanical analysis of the roundhouse kick according to height and distance in taekwondo. Biology of sport / Institute of Sport, December pp. 275-9. doi: 10.5604/20831862.1077553

Falco, C., Landeo, R., Menescardi, C., Ber- mejo, J. \& Estevan, I. (2012). Match Analysis in a University Taekwondo Championship. Advances in Physical Education. 2. pp. 28 31. doi: 10.4236/ape.2012.21005

Heller, J., Peric, T., Dlouha, R., Kohlikovc, E., Melichna, J., \& Novakova, H. (1998). Physiological proofiles of male and female taekwon-do (ITF) black belts. Journal of Sports Sciences, 16, pp. 243-249.

Sant'Ana, J., Diefenthaeler, F., Dal Pupo, J., Detanico, D., Guglielmo, L., G. \& Santos, S. (2014). Anaerobic evaluation of Taekwondo athletes. International Sport Med Journal Vol 15, December pp. 492-499.

Kitagawa, K. (2010). Measurement of blood lactate during sports, Conference: Sport Science and Studies in Asia - Issues, Reflections and Emergent Solutions, doi: 10.1142/9789814304092_0006

Khayyat, H., N., Sağır, S. G., Hataş, O., Smolarczyk, M. \& Akalan, C. (2020). Physical, physiological and psychological profles of elite Turkish taekwondo athletes. Biomedical Human Kinetics, 12(1), pp. 187-196. doi:10.2478/bhk-2020-0024

Laursen, P. B., \& Jenkins, D. G. (2002). The scientific basis for high-intensity interval training: optimising training programmes and maximising performance in highly trained endurance athletes. Sports medicine (Auckland, N.Z.), 32(1), pp. 53-73. https://doi. org/10.2165/00007256-200232010-00003

Markovic G., Vucetic, V. \& Cardinale, M. (2008). "Heart rate and lactate responses to taekwondo fight in elite women performance." Biology of Sport, Vol. 25 No2

Markovic, G., Misigoj-Durakovic, M. \& Trninic, S. (2005). Fitness Profile of Elite Croatian Female Taekwondo Athletes. Collegium antropologicum, 29(1), pp. 93-99.

Newsholme, E., Leech, A. \& Duester, G. (1994). Keep on running: The science of Training and performance. John Wiley \& Sons In- 
corporated.

Parizkova, J. \& Buzkova, P. (1971). Relationship between skinfold thickness measured by Harpenden caliper and densitometric analysis of total body fat in men. Human Biology, 43, pp. 16-21.

Powers, S.K., \& Howley, E.T. (2004). Exercise Physiology: theory and Application to Fitness and Performance 5th ed. New York: McGraw-Hill.

Rivera, M., Rivera-Brown, A. \& Frontera, W. R. (1998). Health Related Physical Fitness Characteristics of Elite Puerto Rican Athletes. The Journal of Strength \& Conditioning Research, Vol. 12. (3), pp. 199-203

Someren, K.A. van. 2006. The physiology of training. Oxford: UK: Elsevier.

Stone, M.H., Sands, W.A., Pierce, K.C., Newton, R. U., Haff, G. G.\& Carlock, J. (2006). Maximum Strength and Strength Training A Relationship to Endurance?, Strength and Conditioning Journal: June 2006 - Volume 28
- Issue 3 - pp. 44-53

World Taekwondo Federation, (2020). Official rules and interpretations. worldtaekwondo. org. http://www.worldtaekwondo.org/viewer_pdf/external/pdfjs-2.1.266-dist/web/viewer.html?file=http://www.worldtaekwondo.org/ att_file/documents/WT\%20Competition $\% 20$ Rules_Interpretation\%20(October\%201,\%20 2020).pdf. Retrieved on May 15, 2021.

World Taekwondo Federation, (2009). WTF Competiton rules. mastkd.com. 4 3. http://mastkd.com/wp-content/uploads /2009/06/2009-06-06_Axx_masTaekwondo_WTF_Competition_Rules_and_Interpretation_GA_Passed_on_Feb_2009.pdf. Retrieved on May 15, 2021.

World Taekwondo Federation, (2019). Results from the 2019 World Taekwondo Championships. http://www.worldtaekwondo.org/ competition/view.html?nid=124471\&mc$\mathrm{d}=\mathrm{A} 01 \& \mathrm{sc}=\mathrm{re} \&$ page $=3$. Retrieved on May $15,2021$.

Corresponding author:

Dimitar Avramov

"Wrestling and Judo" Department 21, Acad. Stefan Mladenov str.

Studentski grad, 1700 Sofia, Bulgaria E-mail: mitkoave@yahoo.com 